\title{
Micro and Macro Determinants of Delisting and Liquidity in Indonesian Stock Market: A Time-Dependent Covariate of Survival Cox Approach
}

\author{
${ }^{1}$ Dedy Dwi Prastyo*, ${ }^{2}$ Yurike Nurmala Rucy, ${ }^{3}$ Advendos D.C. Sigalingging, \\ ${ }^{4}$ Suhartono and ${ }^{5}$ Soo-Fen Fam \\ ${ }^{1,2,3,4}$ Department of Statistics, Institut Teknologi Sepuluh Nopember \\ Kampus ITS - Sukolilo, Surabaya 60111, Indonesia \\ ${ }^{5}$ Department of Technopreneurship, \\ Universiti Teknikal Malaysia Melaka, 76100 Durian Tunggal, Melaka, Malaysia \\ ${ }^{*}$ Corresponding author: dedy-dp@statistika.its.ac.id
}

Article history

Received: 28 September 2018

Received in revised form: 6 December 2018

Accepted: 17 December 2018

Published on line: 31 December 2018

\begin{abstract}
Cox model is popular in survival analysis. In the case of time-varying covariate; several subject-specific attributes possibly to change more frequently than others. This paper deals with that issue. This study aims to analyze survival data with time-varying covariate using a time-dependent covariate Cox model. The two case studies employed in this work are (1) delisting time of companies from IDX and (2) delisting time of company from LQ45 (liquidity index). The survival time is the time until a company is delisted from IDX or LQ45. The determinants are eighteen quarterly financial ratios and two macroeconomics indicators, i.e., the Jakarta Composite Index (JCI) and BI interest rate that changes more frequent. The empirical results show that JCI is significant for both delisting and liquidity whereas BI rate is significant only for liquidity. The significant firm-specific financial ratios vary for delisting and liquidity.
\end{abstract}

Keywords Cox model; delisting; liquidity; survival; time-dependent covariate.

\section{Mathematics Subject Classification 62 N86.}

\section{Introduction}

The removal of a listed company from a stock exchange is called delisting that can be caused by voluntary (seeks to become private) or involuntary. The involuntary delisting usually happens when a company ceases operations, merged, declares bankruptcy, or does not meet listing requirements. It is exciting to know what will happen to shareholders when companies are delisted from stock exchanges. The event does not affect directly to the shareholders as they still own their company with the same proportion of ownership as previously. However, delisting usually occurs after companies go bankrupt or close to bankruptcy, where that situation is a huge financial problem. This paper analyzes two cases: (1) the delisting events happen to the 
companies in Indonesian stock exchange (IDX) that was studied by Prastyo et al. [1] and (2) delisting event in the LQ45 index. The R\&D division of the IDX composes the LQ45 index that consists of 45 stocks satisfying some specific criteria. One of the key principles is that these stocks are among the most liquid traded on the IDX. The list of companies in the LQ45 index is regularly adjusted every six months in February and August.

There are several previous studies about survival analysis applied delisting event in IDX caused by the distress condition suffered by the company as done by Kristanti and Effendi [2] and Prastyo et al. [1]. The other research about survival analysis and financial distress in other countries have been done by Laitinen [3] for Finland case, Lee [4] for companies listed in Taiwan Stock Exchange, Kim et al. [5] for Chinese firms, as well as by Gepp and Kumar [6]. The use of survival analysis for analyzing financial distress causing delisting event was firstly introduced by Shumway [7] who extended the Cox Proportional Hazard Model (PHM) [8]. The basic idea of the Cox PHM can be read in survival analysis literature $[9,10,11]$. Recently, the survival analysis has been developed rapidly and applied widely involving nonparametric and machine learning approach $[12,13]$.

The one step among other can be done to analyze the financial health of a company is by looking more in-depth at financial ratios. These ratios can be used to make comparisons between different aspects of a company's performance [14]. Furthermore, the financial ratios reflect how the company performs within a particular industry or region. The financial ratios can also be considered as micro indicator whereas the macroeconomic indicator possibly affects directly and non-directly to the company's performance. The involvement of macroeconomic indicator in the model can accommodate the indirect dependency among companies $[15,16]$ instead of accommodating the dependence directly among observations that lead to the approach becomes very complicated.

The financial ratio can be calculated from financial reports that are available annually, bi-annually, or quarterly. In this research, the financial ratios as a subject-specific attribute are calculated quarterly. Several financial ratios possibly change more frequently than others. Given that these subject-specific attributes are assigned as a fixed variable, the change in values does not affect the model complexity. This setting will be much different if the dynamic of the predictor is treated as a random variable. The macroeconomic indicators used in this study, i.e., the Jakarta Composite Index (JCI) and interest rate of Bank Indonesia, are available in a shorter period. Thus, these two macroeconomic indicators are computed as an average value or stay constant if there is no change along with the period of financial ratios [1]. The reason why JCI and interest rate of Bank Indonesia are chosen as macroeconomic indicators is based on the empirical results provided by references $[15,16]$. Those two works examined the effect of the market return, which is represented by JCI, to the asset return given Bank Indonesia's interest rate represents the risk-free interest rate. The empirical results showed that these two macroeconomic indicators are relevant to the asset return used in the calculation of several financial ratios.

Due to the covariates change with time, the survival analysis has to be able to accommodate the dynamic of the covariates. Thus, this work employs the Cox PHM with time-dependent covariate approach, see references $[17,18,19]$ for some fundamental idea. The proposed technique is applied to the two cases mentioned above. The rest of this paper is written as literature and method, data and variables, and empirical results. The last part is devoted to the conclusion. 


\section{Cox Model with Time-Dependent Covariate}

Let the time to delisting is denoted as $T$ and time-dependent covariates are $X$. The $X(t)$ represents the value of $X$ at time $t$ and $\bar{X}(t)=\{X(s): 0 \leq s \leq t\}$ denotes the historical values of $X$ until time $t$. The conditional hazard function of $T$ given $\bar{X}(t)$ is formulated as

$$
\lambda(t \mid \bar{X}(t))=P(T \in[t, t+\Delta t) \mid T \geq t, \bar{X}(t)),
$$

with $[t, t+\Delta t)$ is a very small time interval. The Cox PHM [8] specifies the conditional hazard function in Equation (1) such that become positive function as

$$
\lambda(t \mid \bar{X}(t))=\lambda_{0}(t) \exp \left\{\beta^{\prime} \bar{X}(t)\right\}
$$

with $\lambda_{0}(t)$ is unspecified baseline hazard. The vector of parameters $\beta$ in Equation (2) is estimated from observed data using partial likelihood estimation. The survival function conditional on the historical value of $X$ is formulated in Equation (3):

$$
S(t \mid \bar{X}(t))=P(T>t \mid \bar{X}(t)) .
$$

There are $n$ observations such that we have data $\left\{t_{i}, \delta_{i}, \bar{X}\left(t_{i}\right)\right\}$ for $i=1,2, \ldots, n$. The $\delta_{i}$ denotes censoring status for observation $i$, where $\delta_{i}=1$ the event of interest happened, otherwise $\delta_{i}=0$ if it censored at the time $t_{i}$. The parameters $\beta$ are estimated using partial likelihood with score function as follows.

$$
U(\beta)=\sum_{i=1}^{n} \delta_{i}\left(X_{i}\left(t_{i}\right)-\frac{\sum_{j \in R_{i}} \exp \left\{\beta^{\prime} X_{j}\left(t_{i}\right)\right\} X_{j}\left(t_{i}\right)}{\sum_{j \in R_{i}} \exp \left\{\beta^{\prime} X_{j}\left(t_{i}\right)\right\}}\right)
$$

with $R_{i}$ is a collection of individuals who are at risk at the time $t_{i}$, i.e., whose observation times are greater or equal than time $t_{i}$. The estimator $\hat{\beta}$ is the solution for $U(\beta)=0$. The optimization for Equation (4) can be obtained via numerical optimization because the solution is not closed form.

\section{Data and Variables}

There is two datasets used as case studies in this work. The first dataset is delisting manufacture companies from IDX spans from the first quarter (Q1) in 1990 until the third quarter (Q3) in 2015. The period is 103 quarters. If a company survive until the third quarter of 2015, then that company is assigned as right censored. During this period, there are 79 companies observed that consist of 73 companies survives, four companies delisting, and the rest two are relisting. The second dataset is the list of companies delisting from February 2005 until August 2015. The companies that survive until August 2015 are assigned as a right-censored observation. There are 44 quarters within this time interval.

The covariates are two macroeconomic indicators and eighteen financial ratios computed from financial reports provided by Indonesia Capital Market Directory (ICMD). The two macroeconomic indicators are the Jakarta Composite Index (JCI) changing daily even shorter and Bank Indonesia's interest rate that varies irregularly depend on the decision made by the 
Table 1: Financial Ratio

\begin{tabular}{|c|l|c|l|}
\hline No. & Financial ratio & No. & Financial ratio \\
\hline 1 & Earnings per Share & 10 & Net Profit to Margin \\
\hline 2 & Current Asset & 11 & $\begin{array}{l}\text { Earning Power to Total Investment (Operat- } \\
\text { ing Profit / Total Asset) }\end{array}$ \\
\hline 3 & Book Value per Share & 12 & $\begin{array}{l}\text { Total Asset Turnover (Total Revenue / Total } \\
\text { Asset) }\end{array}$ \\
\hline 4 & Debt to Asset Ratio & 13 & Earning to Debt \\
\hline 5 & Debt to Equity Ratio & 14 & $\begin{array}{l}\text { Working Capital (Current Asset - Current } \\
\text { Liabilities) to Total Asset }\end{array}$ \\
\hline 6 & Return on Asset & 15 & Working Capital to Long-Term Debt \\
\hline 7 & Return on Equity & 16 & Retained Earnings to Total Asset \\
\hline 8 & Gross Profit to Margin & 17 & $\begin{array}{l}\text { Book Equity to Total Capital (Book Value } \\
\text { per Share / Total Capital) }\end{array}$ \\
\hline 9 & Operating Profit to Margin & 18 & Fixed Asset Turnover (Sales / Fixed Asset) \\
\hline
\end{tabular}

board of director. To comply with the dynamic of financial ratios that change quarterly, these macroeconomic are adjusted accordingly. The eighteen financial ratios are tabulated in Table 1 .

The financial ratios contain many outliers. The existence of outlier gives significant impact on the data analysis. Therefore, the outliers are winsorized by the 2.5 percent of quantile on the left and $97.5 \%$ of quantile on the right. The descriptive statistics (after then replacement of outliers) of financial ratios of companies listed at IDX are summarized in Table 2. Four financial ratios have skew distribution showed by the bold statistic values.

\section{Empirical Results}

The empirical analysis is firstly provided by computing the empirical survival probability. One of the most commonly used methods is the Kaplan-Meier (KM) curve [9,10,11] which belongs to the nonparametric approach to estimate the survival function of lifetime data. A plot of the KM curve is a series of declining horizontal steps which approach survival function (vertical axis) over the time (horizontal axis). The KM curve for delisting data from IDX is displayed in Figure 1. The left side graph exhibits the KM curve for all data in the list (79 companies) whereas the right side picture is for KM curve for each sub-sector belongs to the manufacturing sector.

Figure 1 shows that all companies observed during the study period have survival probability, on average, higher than $80 \%$ at quarter 103. This number means that manufacture companies have a high likelihood to stay listed at IDX for a long period. If we go more detail by analyzing survival probability for each sub-sector as displayed by the left side graph, then the three sub-sectors have a different chance to stay listed at IDX. The survival probability of companies belongs to consumer goods sub-sector (green curve) decrease much at quarter 80, even before they have a higher survival probability. 
Table 2: Descriptive Statistic of Financial Ratio (IDR)

\begin{tabular}{|c|l|l|l|l|l|}
\hline No. & Financial ratio & Q-1 & Mean & Median & Q-3 \\
\hline 1 & Earnings per Share & 0.00 & $\mathbf{1 4 1 . 0 3}$ & $\mathbf{2 4 . 0 0}$ & $\mathbf{1 3 3 . 5 0}$ \\
\hline 2 & Current Asset & 0.93 & 1.99 & 1.41 & 2.25 \\
\hline 3 & Book Value per Share & 2.00 & $\mathbf{3 1 5 4 . 0 0}$ & $\mathbf{3 6}$ & $\mathbf{2 0 1 . 0 0}$ \\
\hline 4 & Debt to Asset Ratio & 0.39 & 0.66 & 0.56 & 0.73 \\
\hline 5 & Debt to Equity Ratio & 0.40 & 1.20 & 0.98 & 1.76 \\
\hline 6 & Return on Asset & $7 \mathrm{E}-5$ & 0.02 & 0.02 & 0.05 \\
\hline 7 & Return on Equity & 0.01 & 0.06 & 0.05 & 0.12 \\
\hline 8 & Gross Profit to Margin & 0.11 & 0.19 & 0.18 & 0.27 \\
\hline 9 & Operating Profit to Margin & 0.03 & 0.07 & 0.09 & 0.16 \\
\hline 10 & Net Profit to Margin & $\mathbf{8 E - 5}$ & $\mathbf{- 0 . 0 2}$ & 0.04 & 0.11 \\
\hline 11 & $\begin{array}{l}\text { Earning Power to Total Investment } \\
\text { (Operating Profit / Total Asset) }\end{array}$ & 0.01 & 0.05 & 0.04 & 0.08 \\
\hline 12 & $\begin{array}{l}\text { Total Asset Turnover (Total Rev- } \\
\text { enue / Total Asset) }\end{array}$ & 0.23 & 0.55 & 0.43 & 0.74 \\
\hline 13 & Earning to Debt & 0.01 & 0.12 & 0.04 & 0.14 \\
\hline 14 & $\begin{array}{l}\text { Working Capital (Current Asset - } \\
\text { Current Liabilities) to Total Asset }\end{array}$ & -0.03 & 0.05 & 0.12 & 0.27 \\
\hline 15 & Working Capital to Long-Term Debt & -0.09 & 2.73 & 0.48 & 2.58 \\
\hline 16 & Retained Earnings to Total Asset & $\mathbf{- 0 . 1 3}$ & $\mathbf{- 0 . 1 1}$ & 0.08 & 0.22 \\
\hline 17 & $\begin{array}{l}\text { Book Equity to Total Capital (Book } \\
\text { Value per Share / Total Capital) }\end{array}$ & 1.00 & 1.02 & 1.00 & 1.00 \\
\hline 18 & $\begin{array}{l}\text { Fixed Asset Turnover (Sales / Fixed } \\
\text { Asset) }\end{array}$ & 0.48 & 2.85 & 1.06 & 2.42 \\
\hline
\end{tabular}



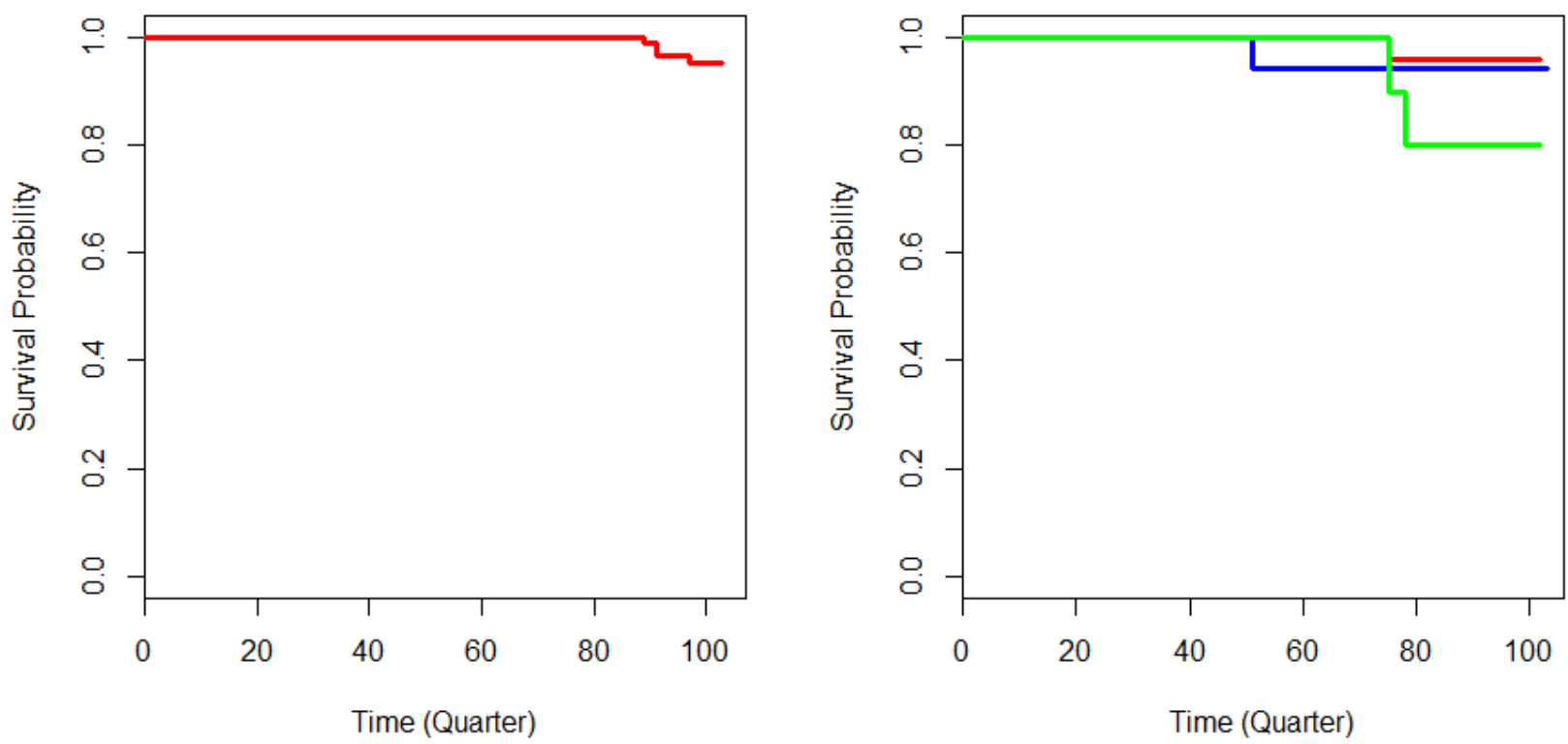

Figure 1: Kaplan-Meier's Survival Function for IDX Data: All Data (Left) and Sub-sector (Right)

The KM curves for listed companies at LQ45 index exhibited in Figure 2. Compared to the survival probability to stay listed at IDX, the probability to survive to stay listed at LQ45 is much smaller. It is not a surprise as the liquidity is dynamic. Also, there is competition among companies to become the top 45 most liquid. It is not the case of listed companies at IDX.

Figure 2 at the left side shows that on average the companies stay at LQ45 has probability no greater than $30 \%$ in quarter 30. Since the LQ45 consist of companies from many (possibly all) sectors, there are many KM curves displayed at the right side graph. The companies from the agriculture sector (red curve) have relatively much smaller survival probability compared to other sectors. This result is very reasonable because Indonesia is a country with a high vulnerability of disaster. Therefore, agriculture companies face high risk caused by the natural disaster. Thus, the liquidity of transaction of those companies at IDX is affected by the risk arise from natural disaster. Other interesting information is shown by a purple curve that shows KM curve for the financial sector. The financial firms survive with relatively high probability for the long term, but for short term, the survival probability decreases dramatically.

The further analysis is Cox modeling that considers the time-varying covariate. The final model produced is resulted from the variable selection using backward elimination based on Akaike's Information Criterion (AIC). The significant estimator of hazard function for IDX data is as follows.

$$
\hat{\lambda}(t \mid \bar{X}(t))=\hat{\lambda}_{0}(t) \exp \{0.290 C R(t)+8.417 G P M(t)-4.941 F A T(t)-0.016 J C I(t)\},
$$

with $C R(t)$ is current ratio at time $t, G P M$ is gross profit to margin ratio, FAT is fixed asset ratio, and $J C I$ is a macroeconomic indicator for Jakarta Composite Index. The AIC value for the model in equation (5) is 30.55 with a $p$-value for the significant determinant $(\alpha=10 \%)$ are as follows: 0.055 for $C R, 0.026$ for GPM, 0.033 for FAT, and 0.033 for JCI.

By using the same procedure for variable selection, the hazard function estimates for LQ45 

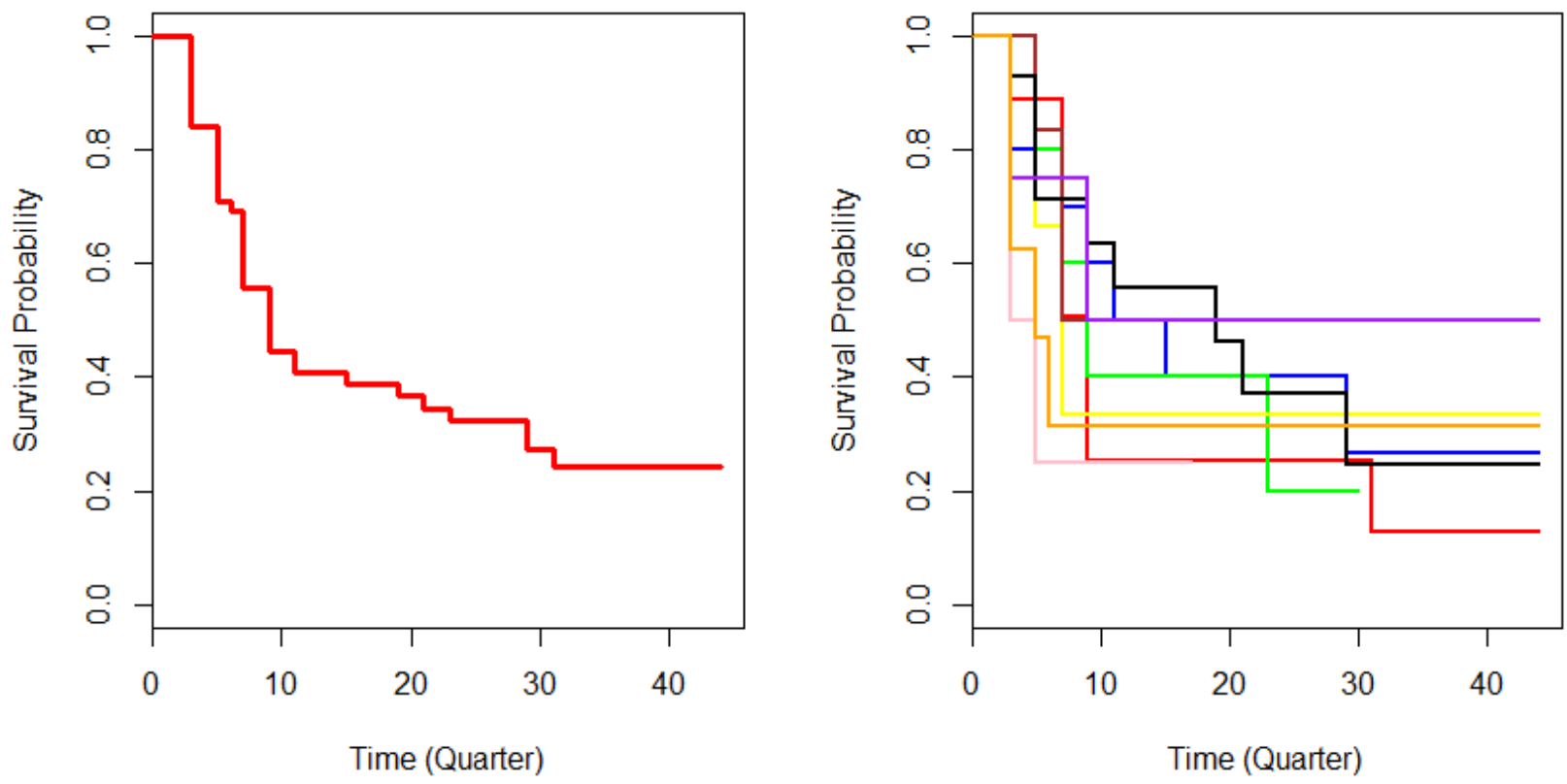

Figure 2: Kaplan-Meier's Survival Function for LQ45 Data: All Data (Left) and Sub-sector (Right)

data is:

$$
\hat{\lambda}(t \mid \bar{X}(t))=\hat{\lambda}_{0}(t) \exp \{A(t)+B(t)+C(t)\}
$$

with

$$
\begin{gathered}
A(t)=3.807 D A R(t)-0.282 \operatorname{DER}(t)-5.990 \text { ROE }(t) \\
B(t)=0.134 \text { WCtoLTD }(t)-3.551 \text { RET } A(t) \\
C(t)=-0.003 J C I(t)-62.990 \text { BIrate }(t),
\end{gathered}
$$

where $D A R$ is a debt to asset ratio, $D E R$ is a debt to equity ratio; $R O E$ is a return on equity ratio, $W C t o L T D$ is working capital (computed as current asset / current liabilities) to longterm debt, RETA is a retained earnings to the total asset. The JCI and BIrate are the two macroeconomic indicators. The AIC value for model in equation (5) is 391.85 with standard error (and $p$-value) for the significant determinant $(\alpha=5 \%)$ are as follows: 0.044 for $D A R$, 0.016 for $D E R, 0.004$ for $R O E, 0.001$ for WCtoLTD, 0.018 for $R E T A$, as well as $\approx 0.000$ for $J C I$ and 0.014 for Bank Indonesia's interest rate.

\section{Conclusion}

Empirical results of this study conclude that the survival probability is higher than eighty percent for manufacture companies listed at IDX. In particular, companies belong to consumer goods sub-sector, the survival probability decrease dramatically at quarter 80. For companies listed at LQ45, the survival probability, on average, no more than thirty percent at quarter 30. The companies listed at LQ45 that belong to agriculture sector have smaller survival probability. According to the Cox model with a time-varying covariate, the Jakarta Composite Index is the macroeconomic indicator that significant for the two case studies whereas the significant financial ratios vary for the two cases. 


\section{Acknowledgement}

This research is financially supported by "Direktorat Jendral Penguatan Riset dan Pengembangan, Kementerian Riset, Teknologi, dan Pendidikan Tinggi" based on the contract between DRPM and ITS number 128/SP2H/PTNBH/DRPM/2018 as well as the contract number 871/PKS/ITS/2018 between ITS and first author as principal investigator.

\section{References}

[1] Prastyo, D. D., Miranti, T., and Iriawan, N. Survival analysis of companies' delisting time in Indonesian stock exchange using bayesian multi-period logit approach. Malaysian Journal of Fundamental and Applied Sciences. 2017. 13(4-1): 425-429.

[2] Kristanti, F. T. and Effendi, N. A survival analysis of Indonesian distressed company using Cox hazard model. Int. Journal of Economics and Management. 2017. 11(S1): 155-167.

[3] Laitinen, E. K. Survival analysis and financial distress prediction: Finnish evidence. Review of Accounting and Finance. 2005. 4(4): 76-90.

[4] Lee, M. C. Business bankruptcy prediction based on survival analysis approach. International Journal of Computer Science and Information Technology. 2014. 6(2): 103-119.

[5] Kim, M. H. Y., Ma, S., and Zhou, Y. A. Survival prediction of distressed firms: evidence from the Chinese special treatment firms. Journal of the Asia Pacific Economy. 2016. 21(3): 418-443.

[6] Gepp, A. and Kumar, K. Predicting financial distress: a comparison of survival analysis and decision tree techniques. In Proceedings of the Eleventh International Multi-Conference on Information Processing (IMCIP 2015), August 21-23. Bangalore: Procedia Computer Science 54. 2015. 396-404.

[7] Shumway, T. Forecasting bankruptcy more accurately: A simple hazard model. The Journal of Business. 2001. 74: 101-124.

[8] Cox, D. R. Regression models and life tables. J. Royal Stat. Soc. Ser. B. 1972. 34: 187-220.

[9] Fleming, T. R. and Harrington, D. P. Counting Processes and Survival Analysis. New York: John Wiley \& Sons. 1996.

[10] Kalbfleisch, J.D. and Prentice, R. L. The Statistical Analysis of Failure Time Data. 2nd Edition. New York: John Wiley and Sons. 2002.

[11] Kleinbaum, D. G. and Klein, M. Survival Analysis: A Self-Learning Text. 3rd Edition. London: Springer. 2012.

[12] Khotimah, C., Purnami, S.W., Prastyo, D.D., Chosuvivatwong, V., and Sriplung, H. Additive survival least square support vector machines: A simulation study and its application to cervical cancer prediction. In Proceedings of the 13th IMT-GT International Conference on Mathematics, Statistics and their Application (ICMSA 2017), December 4-7. Kedah: AIP Conference Proceedings 1905. 050024. 2017.

[13] Khotimah, C., Purnami, S. W., and Prastyo, D. D. Additive survival least square support vector machines and feature selection on health data in Indonesia. In Proceedings of the 1st International Conference on Information and Communications Technology (ICOIACT 2018), March 6-7. Yogyakarta: IEEE Xplore. 2018. 
[14] Haerdle, W. K. and Prastyo, D. D. Embedded predictor selection for default risk calculation: A Southeast Asian industry study. In Chuen, D. L. K. and Gregoriou, G. N. (Eds.). Handbook of Asian Finance, Vol. 1, Financial Market and Sovereign Wealth Fund. San Diego: Academic Press. 2014. 131-148.

[15] Prastyo, D. D., Sudjati, I. L., Fam, S. F., Setiawan, Suhartono, and Satyaning Pradnya Paramita, N. L. P. Value-at-risk modeling on stock return with exogenous variables using ARMAX-GARCHX approach. In Proceedings of the 2nd International Conference on Statistics, Mathematics, Teaching, and Research 2017 (ICSMTR 2017), October 9-10. Makassar: Journal of Physics: Conference Series 1028(1), 012225. 2018.

[16] Prastyo, D. D., Handayani, D., Fam, S.-F., Rahayu, S. P., Suhartono, and Satyaning Pradnya Paramita, N. L. P. Risk evaluation on leading companies in property and real estate subsector at IDX: A value-at-risk with ARMAX-GARCHX approach and duration test. In Proceedings of the 2nd International Conference on Science (ICOS 2017), November 2-3. Makassar: Journal of Physics: Conference Series 979(1), 012094. 2018.

[17] Fisher, D. L. and Lin, D. Y. Time-dependent covariate in the Cox proportional-hazards regression model. Annu. Rev. Public Health. 1999. 20: 145-57.

[18] Lin, D. Y. and Ying, Z. Cox regression with incomplete covariate measurements. J. Am. Stat. Assoc. 1993. 86: 1341-49.

[19] Wei, L. J. Testing goodness of fit for proportional hazards model with censored observations. J. Am. Stat. Assoc. 1984. 79: 649-52. 